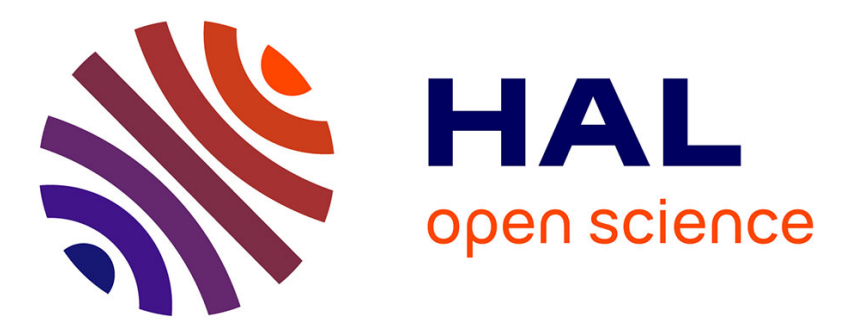

\title{
Non-amplified impedimetric genosensor for quantification of miRNA-21 based on the use of reduced graphene oxide modified with chitosan
}

Michael López Mujica, Yuanyuan Zhang, Fabiana Gutiérrez, Fethi Bedioui, Gustavo Rivas

\section{To cite this version:}

Michael López Mujica, Yuanyuan Zhang, Fabiana Gutiérrez, Fethi Bedioui, Gustavo Rivas. Non-amplified impedimetric genosensor for quantification of miRNA-21 based on the use of reduced graphene oxide modified with chitosan. Microchemical Journal, In press, 10.1016/j.microc.2020.105596 . hal-03021261

\section{HAL Id: hal-03021261 \\ https://hal.science/hal-03021261}

Submitted on 24 Nov 2020

HAL is a multi-disciplinary open access archive for the deposit and dissemination of scientific research documents, whether they are published or not. The documents may come from teaching and research institutions in France or abroad, or from public or private research centers.
L'archive ouverte pluridisciplinaire HAL, est destinée au dépôt et à la diffusion de documents scientifiques de niveau recherche, publiés ou non, émanant des établissements d'enseignement et de recherche français ou étrangers, des laboratoires publics ou privés. 
4 Non-amplified impedimetric genosensor for quantification of miRNA-21 based on the use of reduced graphene oxide modified with chitosan

6 


\section{ABSTRACT}

We report here an impedimetric genosensor for the quantification of microRNA-21 using $\left[\mathrm{Fe}(\mathrm{CN})_{6}\right]^{3-/ 4-}$ as redox probe to transduce the hybridization event. The biosensing platform was built at a thiolated-gold electrode by covalent bond of reduced graphene oxide (RGO) modified with chitosan (CHIT) and further covalent attachment of the aminated DNA probe. GO was used to provide the carboxylic groups for the covalent attachment of CHIT and, once reduced, to improve the electroactivity of the resulting platform, while CHIT served as a bridge between the thiol and the aminated probe DNA. The proposed bioanalytical platform allows the label-free, non-amplified, simple and fast biosensing of microRNA-21, with a linear range between $1.0 \times 10^{-12} \mathrm{M}$ and $1.0 \times 10^{-8} \mathrm{M}$, a sensitivity of $(134 \pm 4)$ $\Omega \mathrm{M}^{-1}\left(\mathrm{r}^{2}=0.996\right)$, a detection limit of $300 \mathrm{fM}$, and a reproducibility of $5.9 \%$ for $1.0 \mathrm{x}$ 10-12 M miRNA-21 and $2.2 \%$ for $1.0 \times 10^{-9} \mathrm{M}$ miRNA-21. The genosensor was successfully used for the quantification of microRNA-21 in enriched human blood serum, urine and saliva samples.

\section{Keywords: microRNA-21; Impedimetric biosensor; Biomarker; Graphene} oxide; Chitosan.

\section{Introduction}

MicroRNAs (miRNAs) are non-coding RNAs of 19-25 nucleotides in length, that can be present in intergenic or intragenic regions of the genome and are involved in the post-transcriptional regulation of gene expression [1]. A dysregulation can be associated with cancer, dementia, and cardiovascular diseases, among other pathologies. miRNAs can have the role of tumor suppression or oncogenic function 
48 and have been connected to-with processes associated with cancer, such as 49 apoptosis, invasion, metastasis, and proliferation [1]. Therefore, the development of 50 highly sensitive and selective methodologies to quantify miRNAs, is highly required.

51 Their low abundance, short length and high sequence-similarity with other family 52 members, make the quantification of miRNAs a big challenge. In the last years there 53 has been an increasing interest for the design of biosensors that allow the sensitive, 54 selective and friendly quantification of miRNAs [2-4]. In this sense, the 55 electrochemical ones have demonstrated to be very efficient [5].

56 miRNA-21 was one of the first mammalian miRNAs identified [6] and has 57 been proposed as diagnostic and prognostic biomarker, and even as therapeutic 58 target for several types of cancer [7]. The upregulation of miRNA-21 in breast, 59 pancreatic, prostate, and colorectal cancers, makes a non-invasive diagnostic 60 biomarker. Therefore, as it is upregulated in several types of cancer, is convenient 61 to use miRNA-21 as part of a panel of biomarkers instead of a specific biomarker for 62 one type of cancer [1].

63 Most of the electrochemical miRNA-21 biosensors reported in the last couple 64 of years have been mainly based on the use of different amplification strategies. 65 Zhang $\mathrm{H}$. et al. [8] reported the use of a hairpin DNA modified-Au electrode 66 associated with the action of a duplex specific nuclease (DSN), and the incorporation 67 of a biotinylated signaling DNA/streptavidin-modified Au68 nanoparticles(NPs)/biotinylated-horseradish peroxidase (HRP) to generate an 69 enhanced analytical signal in the presence of hydrogen peroxide and $703,3,5,5^{\prime}$ tetramethylbenzidine (TMB). A signal amplification mediated by PdNPs 71 accumulated at a guanine-rich ssDNA generated through rolling circle amplification 
72 (RCA) was also proposed [9]. Guo et al. [10] described the sub-fM biosensing by

73 combination of a dual signal amplification strategy using hybridization chain reaction

74 (HCR) and enzyme induced metallization (EIS). Tian et al. [11] described the use of

75 a hairpin capture probe immobilized at $\mathrm{Fe}_{3} \mathrm{O}_{4}$, which is opened after interacting with

76 miRNA-21, to allow the amplification by HCR and the synergized catalytic reduction

77 of hydrogen peroxide/TMB system in the presence of a $\mathrm{Cu}(\mathrm{II})$ planar complex. Liang

78 et al. [12] presented the pM detection of miRNA-21 using an amplification scheme

79 based on HCR in connection with different strategies to transduce the hybridization

80 event. An impedimetric quantification of miRNA-21, reported by Zhang et al. [13],

81 was based on the use of glassy carbon electrode (GCE) modified with $\mathrm{ZrO}_{2}$,

82 graphene oxide (GO) and polyacrylic acid (PAA) containing the cyclically generated

83 dsDNA from the hairpin unfolded after hybridization. The electrostatically

84 accumulated $\left[\mathrm{Ru}(\mathrm{NH})_{6}\right]^{3+}(\mathrm{RuHex})$ at different platforms following diverse schemes

85 was used to generate the analytical signal either with or without the catalytic effect

86 of $\left[\mathrm{Fe}(\mathrm{CN})_{6}\right]^{3-}[14-16]$. Feng et al. [17] proposed the voltammetric (SWV)

87 quantification of miRNA-21 from the molybdophosphate generated through the

88 facilitated accumulation of molybdate at the phosphate residues of the resulting DNA

89 using HCR. Chen et al. [18] described a biosensor based on the SWV signal of the

90 methylene blue (MB) released from mesoporous silica nanospheres-hairpin $\mathrm{H} 1$ and

91 intercalated within the dsDNA generated at the gold electrode/capture DNA as a

92 consequence of $\mathrm{CHR}$ after H1-miRNA-21 hybridization and $\mathrm{CHA}$ in the presence of

93 the hairpin $\mathrm{H} 2$. A ratiometric scheme based on the different currents ratio of two

94 redox markers before and after hybridization through mismatched catalytic hairpin

95 assembly (CHA) amplification and generation of stable "Y"-shaped DNA complexes, 
96 was reported by Li et al. [19]. Pingarrón's group [20] reported an innovative 97 alternative for the sub-pM detection of miRNA-21 using streptavidin-modified 98 magnetic beads in connection with geno- and immunoassays and the detection at a 99 magneto SPE through the use of anti DNA-RNA antibody modified with HRP. A 100 highly sensitive DPV-detection of miRNA-21 through the sandwich hybridization with 101 a thiolated capture probe-AuNPs-modified GCE and a MWCNTs-thionin-signaling 102 probe, was also reported [21].

Although the non-amplified miRNA-21 electrochemical biosensors are not 104 very frequent, some interesting alternatives have been also reported. Luo et al. [22] 105 proposed the $\mathrm{fM}$ ratiometric detection of exosomal miRNA-21 using two redox 106 markers located in a $\mathrm{Y}$ shape-like structure before and after hybridization. 107 Ghazizadeh et al. [23] presented an original strategy by modifying SPE with MCF108 exosomes and the protein p19. Kaugkamano et al. [24] described the fM detection 109 of miRNA-21 through the decrease of $\mathrm{Ag}$ oxidation signal at $\mathrm{Au}$ modified with 110 polypyrrol/Ag and pyrrolidinyl PNA. Bharti et al. [25] proposed the use of fluorine tin 111 oxide (FTO) properly modified to support the biotinylated probe and the , with 112 transduction of the hybridization event through the decrease of the DPV signal of $113\left[\mathrm{Fe}(\mathrm{CN})_{6}\right]^{3-14-}$. The sub-pM detection of miRNA-21 based on the decrease of the 114 SWV-thionin-redox signal at GCE/MoS ${ }_{2}$-thionine-AuNPs was described by Zhu et al. 115 [26]. Azzouzi et al. [27] proposed the impedimetric detection of miRNA-21 through 116 the increment of the charge transfer resistance of a redox mediator produced by the 117 anchoring of the complex biotin-molecular beacon-AuNPs-hybrid at the 118 GCE/neutravidin. 
The present work is focused on the development of a non-amplified 120 impedimetric biosensor for miRNA-21 quantification taking advantage of the unique

121 properties of graphenaceous materials in a double role of anchoring support to 122 covalently immobilize the amine-rich polymer chitosan (CHIT) as graphene oxide 123 (GO) and, as reduced graphene oxide (RGO), to improve to electroactivity of the 124 resulting platform. The biosensing supramolecular architecture was built at 3125 mercapto-1-propanesulfonate-modified gold electrode by self-assembling of RGO126 CHIT and covalent attachment of $\mathrm{NH}_{2}$-DNA probe. The transduction of the 127 hybridization event was obtained from the change of the charge transfer resistance $128\left(\mathrm{R}_{\mathrm{ct}}\right)$ using $\left[\mathrm{Fe}(\mathrm{CN})_{6}\right]^{3-/ 4-}$ as redox marker. In the following sections we discuss the 129 characterization of the biosensing platform and the analytical performance of the 130 resulting genosensor.

131

132 2. Experimental

133 2.1. Reagents

134 Sodium 3-mercapto-1-propanesulfonate (MPS), glutaraldehyde (glu), 135 chitosan (CHIT), N-(3-dimethylaminopropyl)-N'-ethylcarbodiimide hydrochloride 136 (EDC), N-hydroxy-succinimide (NHS), and bovin serum albumin (Alb) were 137 purchased from Sigma. Potassium ferrocyanide was obtained from Merck and 138 potassium ferricyanide from Biopack. Ethanol, sulfuric acid (98\%) and sodium 139 hydroxide were provided by J. T. Baker. Graphene oxide (GO, aqueous dispersion $1404.0 \mathrm{mg} \mathrm{mL}^{-1}$ ) was obtained from Graphenea. Other chemicals were reagent grade 141 and used without further purification. DNA and RNA sequences, obtained from 142 Invitrogen Life Technologies, are the following: 
DNA probe: 5'-NH2-TCA-ACA-TCA-GTC-TGA-TAA-GCT-A-3'

144

miRNA-21: 5'-UAG-CUU-AUC-AGA-CUG-AUG-UUG-A-3'

145

Single-base mismatch: 5'-UAG-CUU-AUC-AㅡA-CUG-AUG-UUG-A-3'

146

Non-complementary sequence: 5’-GGG-GGG-GGG-GGG-GGG-GGG-GGG-3'

147

Ultrapure water $(\rho=18.2 \mathrm{M} \Omega \mathrm{cm}$ ) from a Millipore-MilliQ system was used for 148 preparing all the solutions.

149

150

\subsection{Apparatus}

151 A platinum wire and $\mathrm{Ag} / \mathrm{AgCl}, 3 \mathrm{M} \mathrm{NaCl}(\mathrm{BAS})$ were used as counter and reference 152 electrodes, respectively. All potentials are referred to the latter. The gold working 153 electrodes were cleaned before each experiment by successive mechanical, 154 chemical and electrochemical treatment. The mechanical treatment consisted in 155 polishing with $0.05 \mu \mathrm{m}$ alumina for $6 \mathrm{~min}$, followed by sonication in deionized water 156 for 5 min. Chemical treatment was performed by immersion in "Piranha" solution (1:3 $157 \mathrm{v} / \mathrm{v} \mathrm{H}_{2} \mathrm{O}_{2} / \mathrm{H}_{2} \mathrm{SO}_{4}$ ) for $5 \mathrm{~min}$, followed by sonication for 10 seconds in ultrasonic bath 158 and rinsing with ultrapure water. During the electrochemical treatment, the surfaces 159 were stabilized in $0.500 \mathrm{M} \mathrm{H}_{2} \mathrm{SO}_{4}$ solution by applying two consecutives step 160 potentials of $2.0 \mathrm{~V}$ and $-1.0 \mathrm{~V}$ for 2 and 4 seconds, respectively. The state of the 161 surface after the pretreatment was evaluated by cyclic voltammetry at $0.100 \mathrm{Vs}^{-1}$ in 162 a $0.500 \mathrm{M} \mathrm{H}_{2} \mathrm{SO}_{4}$ solution.

163 Electrochemical Impedance Spectroscopy (EIS) measurements were 164 performed with a PGSTAT30 potentiostat (Methrom). The redox probes were $1.0 \mathrm{x}$ $16510^{-3} \mathrm{M}\left[\mathrm{Fe}(\mathrm{CN})_{6}\right]^{3-} /\left[\mathrm{Fe}(\mathrm{CN})_{6}\right]^{4-}$ and the experiments were carried out in a $0.050 \mathrm{M}$ 
166 phosphate buffer solution $\mathrm{pH}$ 7.40. EIS parameters were the following, amplitude:

$1670.010 \mathrm{~V}$, frequency range: between $1.0 \times 10^{-2}$ and $1.0 \times 10^{6} \mathrm{~Hz}$, and working

168 potential: $0.200 \mathrm{~V}$. The impedance spectra were analyzed and fitted by using the Z169 view program.

170

UV-Vis experiments were carried out with a Shimadzu UV1601

171 spectrophotometer and a quartz cuvette of $0.1 \mathrm{~cm}$ path length.

172

173

\subsection{Synthesis of RGO-CHIT}

174

A volume of $3.125 \mathrm{~mL}$ of $4.0 \mathrm{mgmL}^{-1} \mathrm{GO}$ solution was mixed with $6.875 \mathrm{~mL}$ 175 of a $2.00 \mathrm{mgmL}^{-1}$ CHIT solution previously prepared in a $0.100 \mathrm{M} \mathrm{2-(N-}$ 176 morpholino)ethanesulfonic acid (MES) $\mathrm{pH} 5.00$ by sonicating for $2 \mathrm{~h}$ in ultrasonic 177 bath. The resulting GO-CHIT mixture was sonicated in ultrasonic bath for $2 \mathrm{~h}$ to 178 obtain a homogeneous dispersion. After that, the carboxylate groups of GO were 179 activated with $0.100 \mathrm{M}$ EDC and $0.100 \mathrm{M}$ NHS by sonication for 2 hours and 180 overnight reaction until completeness under stirring conditions. The purification of 181 GO-CHIT was carried out by centrifugation for $60 \mathrm{~min}$ at $3500 \mathrm{rpm}$ and further 182 resuspension of the pellet in a $0.15 \mathrm{M}$ MES buffer $\mathrm{pH} 5.00$. This process was 183 repeated 4 times to eliminate the excess of CHIT. Subsequently, RGO-CHIT was 184 chemically reduced by adding excess of $\mathrm{NaBH}_{4}$ and stirring for $24 \mathrm{~h}$. The resulting 185 RGO-CHIT was washed following the same procedure as indicated before for 186 washing GO-CHIT. The characterization of the synthesis was carried out by UV-vis 187 spectroscopy, following the displacement of the GO extinction band at $234 \mathrm{~nm}$ 188 (Figure 1-SI). 


\subsection{Construction of the biosensing platform}

Figure 1 presents a schematic illustration of the different steps followed during 192 the construction of the biosensing platform. The gold electrode was modified with a $1932.00 \times 10^{-2} \mathrm{M}$ MPS solution (prepared in $1.60 \times 10^{-3} \mathrm{M} \mathrm{H}_{2} \mathrm{SO}_{4}$ ) for 60 min. After 194 washing the surface with the sulphuric acid solution and water, RGO-CHIT was 195 electrostatically adsorbed for $60 \mathrm{~min}$. Once the RGO-CHIT was immobilized at the 196 electrode surface and after washing with MES, the amine residues were activated 197 with $1.0 \%$ v/v glutaraldehyde (prepared in $1 \% \mathrm{v} / \mathrm{v} \mathrm{CH}_{3} \mathrm{COOH}$ ). Previous washing of 198 the surface with $0.050 \mathrm{M}$ phosphate buffer solution $\mathrm{pH} 7.40$, the probe was

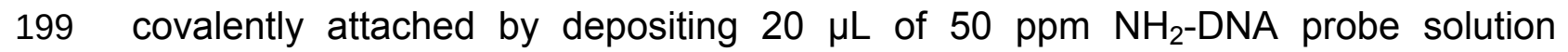
200 (prepared in $0.050 \mathrm{M}$ phosphate buffer $\mathrm{pH} 7.40+0.500 \mathrm{M} \mathrm{NaCl}$ ) at the electrode 201 surface for $30 \mathrm{~min}$. After this step, the surface was washed with $0.050 \mathrm{M}$ phosphate 202 buffer $\mathrm{pH} 7.40+0.500 \mathrm{M} \mathrm{NaCl}$ and before performing the hybridization, the surface 203 was blocked with $2.0 \% \mathrm{w} / \mathrm{v}$ albumin for $30 \mathrm{~min}$ to avoid non-specific adsorptions. 204 The hybridization was performed at the resulting Au/MPS/RGO-CHIT/DNA probe 205 biosensing platform by dropping the $20 \mu \mathrm{L}$ of miRNA-21 solution (prepared in 0.050 $206 \mathrm{M}$ phosphate buffer solution $\mathrm{pH} 7.40+0.500 \mathrm{M} \mathrm{NaCl}$ ) for $75 \mathrm{~min}$.

\section{Results and discussion}

209 Figure 2A shows the Nyquist plots obtained after each step during the 210 construction of the biosensing supramolecular arquitecture ( $\mathrm{Au}, \mathrm{Au} / \mathrm{MPS}$, 211 Au/MPS/RGO-CHIT, Au/MPS/RGO-CHIT/DNA probe $_{1} \quad$ Au/MPS/RGO-

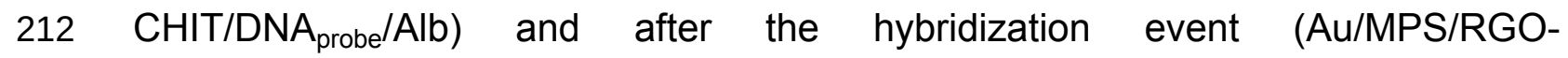
$213 \mathrm{CHIT/DNA}$ probe $\left./ \mathrm{miRNA}^{2} 21\right)$ using $\left.1.0 \times 10^{-3} \mathrm{M}\left[\mathrm{Fe}(\mathrm{CN})_{6}\right]^{3-}\right] /\left[\mathrm{Fe}(\mathrm{CN})_{6}\right]^{4-}$ as redox 
214 probe. The circles correspond to the experimental points while the solid lines 215 represent the fitting with the model, in this case a Randles circuit, where $R_{S}$ is the 216 solution resistance, $R_{c t}$ is the charge transfer resistance, $C_{d l}$ the capacitance of the 217 double-layer and W, the Warburg impedance (Inset of Figure 2A). Figure 2B depicts 218 the variation of $R_{c t}$ obtained from the Nyquist plots shown in Figure $2 A$. The 219 attachment of MPS at Au produced the expected increment of $R_{c t}$ due to the blocking 220 effect of the thiol and the electrostatic repulsion with the redox marker. The 221 adsorption of RGO-CHIT does not produce a significant change in $\mathrm{R}_{\mathrm{ct}}$ due to the 222 compensation of different effects: the facilitated electrostatic interaction between $223 \mathrm{CHIT}$ and $\left.\left[\mathrm{Fe}(\mathrm{CN})_{6}\right]^{3-}\right] /\left[\mathrm{Fe}(\mathrm{CN})_{6}\right]^{4-}$ and the conductive nature of RGO that would 224 facilitate the charge transfer, and the blocking effect of CHIT that would make more 225 difficult the charge transfer of the redox probe. Once the DNA probe is immobilized 226 at $\mathrm{Au} / \mathrm{MPS} / \mathrm{RGO}-\mathrm{CHIT}, \mathrm{R}_{\mathrm{ct}}$ increases due to the blocking effect of the non227 conductive nucleic acid layer and the electrostatic repulsion of the redox marker with 228 the negatively charge ribose-phosphate backbone of DNA. The incorporation of Alb, 229 to avoid the non-specific adsorption, produces a small decrease of $R_{c t}$ mainly due to 230 the shielding of the negative charges of DNA probe that compensates the blocking 231 effect of the non-conductive protein. Once the hybridization with $1.0 \times 10^{-8} \mathrm{M}$ miRNA23221 takes place, there is an important increment of $R_{c t}$ due to the increase of the 233 electrostatic repulsion between the redox probe and the higher negative charge 234 density as a consequence of the surface heteroduplex formation.

235 The effect of the hybridization time was evaluated from similar experiments 236 performed with $1.0 \times 10^{-9} \mathrm{M}$ miRNA-21. There was an increment in the $R_{c t}$ with the 237 hybridization time from 30 to 75 min mainly due to the increase of the electrostatic 
repulsion between the redox marker and the enhanced negative charge density 239 resulting from the formation of a higher amount of DNA-miRNA-21 with the 240 hybridization time, to slightly decrease thereafter (Figure 2-SI). We selected 75 min 241 as the best compromise between sensitivity, reproducibility and assay time.

Figure $3 \mathrm{~A}$ depicts the Nyquist plots obtained for Au/MPS/RGO-CHIT/DNA/Alb

243 in the presence of different concentrations of miRNA-21 from $1.0 \times 10^{-12} \mathrm{M}$ to $1.0 \mathrm{x}$ $24410^{-8} \mathrm{M}$, and Figure $3 \mathrm{~B}$ shows the plot of the corresponding $R_{\mathrm{ct}}$ as a function of 245 miRNA-21 concentration. There is a linear dependence in the whole range between $2461.0 \times 10^{-12} \mathrm{M}$ and $1.0 \times 10^{-8} \mathrm{M}$ miRNA-21, with a sensitivity of $(134 \pm 4) \Omega \mathrm{M}^{-1}\left(\mathrm{r}^{2}=\right.$ 247 0.996) and a detection limit of $300 \mathrm{fM}$ (calculated as $3 \times \mathrm{SD} / \mathrm{s}$ where SD is the 248 standard deviation of the blank signal and s, the sensitivity). The reproducibility, 249 obtained from the determination of $1.0 \times 10^{-12} \mathrm{M}$ miRNA-21 was $5.9 \%$ while for 1.0 250 x $10^{-9} \mathrm{M}$ miRNA-21, it was $2.2 \%$.

251 Figure 4 shows the bars plot for the $R_{c t}$ of the redox marker obtained at

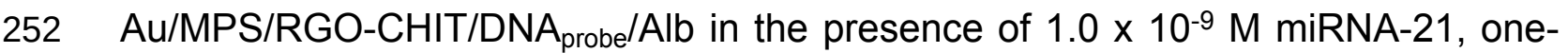
253 base mismatch sequence and a fully non-complementary sequence, to evaluate the 254 selectivity of the genosensor. No response was observed in the case of the fully non255 complementary sequence compared to the blank while for the one-base mismatch 256 sequence, the $R_{c t}$ is only $24.2 \%$ of the complementary one, clearly indicating that 257 the genosensor is able to discriminate non-complementary and even one-base 258 mismatch sequences.

259 Considering that miRNA-21 can be found in different biological fluids and that, 260 depending on the nature of the cancer, it is relevant to use one or other fluid, we 261 evaluate the usefulness of our biosensor to quantify miRNA-21 in: saliva, urine and 
reconstituted human serum samples diluted (1:10 (saliva and urine) and 1:1000

263 (serum samples)), with $0.050 \mathrm{M}$ phosphate buffer solution $\mathrm{pH} 7.40+0.500 \mathrm{M} \mathrm{NaCl}$ )

264 and enriched with $1.0 \times 10^{-9} \mathrm{M}$ miRNA-21. The recovery values were (96 \pm 3$) \%$, (90

$265 \pm 2) \%$, and $(98 \pm 3) \%$ for urine, saliva and serum, respectively. It is important that

266 analogue experiments performed with the diluted samples without miRNA-21, did

267 not show any matrix effect, with interferences in $\mathrm{R}_{\mathrm{ct}}$ of $1.9 \%, 2.3 \%$ and $1,0 \%$ for

268 reconstituted serum, urine and saliva, respectively. These results indicate that the

269 proposed genosensor can be successfully used for practical applications in different

270 biological fluids.

271 Table 1 compares the analytical performance of our biosensor with the most

272 relevant miRNA-21 electrochemical biosensors reported in the last couple of years.

273 Among them, most of the electrochemical biosensors based on the use of

274 amplification schemes detection limits (femtomolar to attomolar) than our biosensor 275 (300 fM) [8-11, 13-19, 25] while few of the amplified biosensors present higher 276 detection limits than the proposed biosensing platform [12, 20]. Regarding the non277 amplified detection, our biosensor presents better detection limits than the strategies 278 reported in references $[26,27]$ and higher than those described in references $[23$, 279 24]. In summary, even when our biosensor does not present better detection limits 280 than most of the biosensors reported in the Table 1, it is still competitive since it is 281 possible to quantify miRNA-21 even at fM levels in a simple and fast way, without 282 using amplification strategies involving labelling enzymes/redox markers, 283 endonucleases, special isothermal amplification schemes, different nanomaterials, 284 oligonucleotides with particular structures, and DNA analogues [8-11, 13-19, 25] or 
non-amplified strategies based on the use of expensive noble metal nanoparticles

$286[21,24,25]$.

287

288

\section{CONCLUSIONS}

289

This work reported an original, label-free and non-amplified impedimetric

290

291

292

of RGO to improve the electroactivity of the platform, and the high density of the

293 amine groups of chitosan to work as bridge between MPS and the aminated capture

294 probe. The resulting genosensor allowed the sensitive (femtomolar), selective,

295 simple and fast quantification of miRNA-21 without any additional amplification step 296 and successful application in different biological fluids.

297

In addition to these advantages for the quantification of miRNA-21, that make 298 Au/MPS/RGO-CHIT/DNA competitive, it is a versatile bioanalytical platform that 299 opens new horizons for multiple biosensing applications just selecting the most 300 appropriate biorecognition element.

301

302

\section{ACKNOWLEDGEMENTS}

303

Financial support from CONICET, ANPCyT, SECyT-UNC (Argentina) and

304 ECOS-SUD program (A16E02). M. L.-M. thankfully acknowledges CONICET for the 305 PhD fellowship. Y. Zhang thanks Chinese Scholarchip Council for providing a three306 year scholarship for her stay in France and LabEx MICHEM for supporting her living 307 expenses in Argentina

308 
309

310

311

312

313

314

315

316

317

318

319

320

321

322

323

324

325

326

327

328

329

330

331

\section{DECLARATION OF CONFLICT OF INTEREST}

No authors have any conflicts of interest to disclose.

\section{REFERENCES}

1. D. Bautista-Sánchez, C. Arriaga-Canon, A. Pedroza-Torres, A. De La RosaVelázquez, R. González-Barrios, L. Contreras-Espinosa, R. MontielManríquez, C. Castro-Hernández, V. Fragoso-Ontiveros, R. María ÁlvarezGómez, L.A. Herrera, The Promising Role of miR-21 as a Cancer Biomarker and Its Importance in RNA-Based Therapeutics, Molec. Ther.: Nuc. Aci. 20 (2020) 409-420.

2. M.K. Masud, M. Umer, M.S.A. Hossain, Y. Yamauchi, N.T. Nguyen, M.J.A. Shiddiky, Nanoarchitecture Frameworks for Electrochemical miRNA Detection, Trends Biochem. Sci. 44 (2019) 433-452.

3. P. Gillespie, S. Ladame, D. O'Hare, Molecular methods in electrochemical microRNA detection, Analyst 144 (2019) 114-129.

4. M. López Mujica, Y. Zhang, F. Bédioui, F. Gutiérrez, G. Rivas, Label-free graphene oxide-based SPR genosensor for the quantification of microRNA21, Anal. Bioanal. Chem. 412 (2020) 3539-3546.

5. H. Mohammadi, G. Yammouri, A. Amine, Current advances in electrochemical genosensors for detecting microRNA cancer markers, Curr. Opin. Electroche. 16 (2019) 96-105.

6. M. Lagos-Quintana, R. Rauhut, W. Lendeckel, T. Tuschl, Identification of novel genes coding for small expressed RNAs, Science 294 (2001) 853-858. 
332 7. R. Rupaimoole, F. Slack, MicroRNA therapeutics: towards a new era for the management of cancer and other diseases, Nat. Rev. Drug Discov. 6 (2017) 203-222.

8. H. Zhang, M. Fan, J. Jiang, Q. Shen, C. Cai, J. Shen, Sensitive electrochemical biosensor for MicroRNAs based on duplex-specific nucleaseassisted target recycling followed with gold nanoparticles and enzymatic signal amplification, Anal. Chim. Acta. 1064 (2019) 33-39.

9. C. Zhang, D. Li, D. Li, K. Wen, X. Yang, Y. Zhu, Rolling circle amplificationmediated: In situ synthesis of palladium nanoparticles for the ultrasensitive electrochemical detection of microRNA, Analyst 144 (12) (2019) 3817-3825.

10.W.J. Guo, Z. Wu, X.Y. Yang, D.W. Pang, Z.L. Zhang, Ultrasensitive electrochemical detection of microRNA-21 with wide linear dynamic range based on dual signal amplification, Biosens. Bioelectron. 131 (2019) 267-273.

11.L. Tian, J. Qi, O. Oderinde, C. Yao, W. Song, Y. Wang, Planar intercalated copper (II) complex molecule as small molecule enzyme mimic combined with $\mathrm{Fe}_{3} \mathrm{O}_{4}$ nanozyme for bienzyme synergistic catalysis applied to the microRNA biosensor, Biosens. Bioelectron. 110 (2018) 110-117.

12. M. Liang, M. Pan, J. Hu, F. Wang, X. Liu, Electrochemical Biosensor for MicroRNA Detection Based on Cascade Hybridization Chain Reaction, ChemElectroChem. 5 (2018) 1380-1386.

13. K. Zhang, N. Zhang, L. Zhang, H. Wang, H. Shi, Q Liu, Label-free impedimetric sensing platform for microRNA-21 based on $\mathrm{ZrO}_{2}$-reduced graphene oxide nanohybrids coupled with catalytic hairpin assembly amplification, RSC Adv. 8 (2018) 16146-16151. 
356 14. B. Bo, T. Zhang, Y. Jiang, H. Cui, P. Miao, Triple Signal Amplification Strategy

357 for Ultrasensitive Determination of miRNA Based on Duplex Specific Nuclease

$358 \quad$ and Bridge DNA-Gold Nanoparticles, Anal. Chem. 20 (2018) 2395-2400.

359 15.A. Ganguly, J. Benson, P. Papakonstantinou, Sensitive chronocoulometric

360 detection of miRNA at screen-printed electrodes modified by gold-decorated

$361 \quad \mathrm{MoS}_{2}$ nanosheets, ACS Appl. Bio Mater. 1 (2018) 1184-1194.

362 16. M.N. Islam, L. Gorgannezhad, M.K. Masud, S. Tanaka, M.S.A. Hossain, Y.

363 Yamauchi, N.T. Nguyen, M.A. Shiddiky, Graphene-Oxide-Loaded

364 Superparamagnetic Iron Oxide Nanoparticles for Ultrasensitive

$365 \quad$ Electrocatalytic Detection of MicroRNA, ChemElectroChem. 5 (2018) 2488-

3662495.

367 17. K. Feng, J. Liu, L. Deng, H. Yu, M. Yang, Amperometric detection of microRNA

368 based on DNA-controlled current of a molybdophosphate redox probe and 369 amplification via hybridization chain reaction, Microchim. Acta 185 (2018) $370 \quad 185: 28$.

371 18. H. Cheng, W. Li, S. Duan, J. Peng, J. Liu, W. Ma, H. Wang, X. He, K. Wang, 372 Mesoporous Silica Containers and Programmed Catalytic Hairpin 373 Assembly/Hybridization Chain Reaction Based Electrochemical Sensing 374 Platform for MicroRNA Ultrasensitive Detection with Low Background, Anal. $375 \quad$ Chem. 91 (2019) 10672-10678.

376 19.X. Li, B. Dou, R. Yuan, Y. Xiang, Mismatched catalytic hairpin assembly and 377 ratiometric strategy for highly sensitive electrochemical detection of microRNA 378 from tumor cells, Sensor Actuat. B-Chem. 286 (2019) 191-197. 
20.E. Vargas, R.M. Torrente-Rodríguez, V.R.V. Montiel, E. Povedano, M. Pedrero, J.J. Montoya, S. Campuzano, J.M. Pingarrón, Magnetic beads-based sensor with tailored sensitivity for rapid and single-step amperometric determination of miRNAs, Int. J. Mol. Sci. 18 (2017) 2151.

21. K. Deng, X. Liu, C. Li, H. Huang, Sensitive electrochemical sensing platform for microRNAs detection based on shortened multi-walled carbon nanotubes with high-loaded thionin, Biosens. Bioelectron. 117 (2018) 168-174.

22. L. Luo, L. Wang, L. Zeng, Y. Wang, Y. Weng, Y. Liao, T. Chen, Y. Xia, J. Zhang, J. Chen, A ratiometric electrochemical DNA biosensor for detection of 388 exosomal MicroRNA, Talanta 207 (2020) 120298.

23.E. Ghazizadeh, Z. Naseri, M.R. Jaafari, M. Forozandeh-Moghadam, S. Hosseinkhani, A fires novel report of exosomal electrochemical sensor for sensing micro RNAs by using multi covalent attachment p19 with high sensitivity, Biosens. Bioelectron. 113 (2018) 74-81.

24. T. Kangkamano, A. Numnuam, W. Limbut, P. Kanatharana, T. Vilaivan, P. Thavarungkul, Pyrrolidinyl PNA polypyrrole/silver nanofoam electrode as a novel label-free electrochemical miRNA-21 biosensor, Biosens. Bioelectron. 102 (2018) 217-225.

25. A. Bharti, N. Agnihotri, N. Prabhakar, A voltammetric hybridization assay for microRNA-21 using carboxylated graphene oxide decorated with goldplatinum bimetallic nanoparticles, Microchim. Acta 186 (2019) 185.

400 26. D. Zhu, W. Liu, D. Zhao, Q. Hao, J. Li, J. Huang, J. Shi, J. Chao, S. Su, L. 401 Wang, Label-Free Electrochemical Sensing Platform for MicroRNA-21 
402 Detection Using Thionine and Gold Nanoparticles Co-Functionalized $\mathrm{MoS}_{2}$

$403 \quad$ Nanosheet, ACS Appl. Mater. Inter. 9 (2017) 35597-35603.

404 27.S. Azzouzi, W.C. Mak, K. Kor, A.P.F. Turner, M.B. Ali, V. Beni V, An integrated

405 dual functional recognition/amplification bio-label for the one-step

406 impedimetric detection of Micro-RNA-21, Biosens. Bioelectron. 92 (2017) 154-

$407 \quad 161$.

408

409

410

411

412

413

414

415

416

417

418

419

420

421

422

423

424

425

426

427

428

429

430

431

432

433

434

435

436

437

438

439

440

441

442

443 


\section{LEGENDS OF THE FIGURES}

445

446 Figure 1. Schematic representation of the different steps during the building of the 447 miRNA-21 genosensor.

448

449 Figure 2. (A) Nyquist plots obtained during the construction of biosensor. Inset: 450 Equivalent circuit used to fit the experimental results (B) Charge transfer resistance 451 after each step during the construction of the biosensing layer and after the 452 hybridization with $1.0 \times 10^{-8} \mathrm{M}$ miRNA-21. Redox marker: $1.0 \times 10^{-3} \mathrm{M}$ $453\left[\mathrm{Fe}(\mathrm{CN})_{6}\right]^{3-} /\left[\mathrm{Fe}(\mathrm{CN})_{6}\right]^{4-}$; Frequency range: $10 \mathrm{KHz}$ to $10 \mathrm{mHz}$; Potential amplitude: $45410 \mathrm{mV}$; Working potential: $0.200 \mathrm{~V}$. Supporting electrolyte: $0.050 \mathrm{M}$ phosphate buffer 455 solution $\mathrm{pH} 7.40$ with $0.500 \mathrm{M} \mathrm{NaCl}$.

456

457 Figure 3. (A) Nyquist plots for $1.0 \times 10^{-3} \mathrm{M}\left[\mathrm{Fe}(\mathrm{CN})_{6}\right]^{3-} /\left[\mathrm{Fe}(\mathrm{CN})_{6}\right]^{4-}$ obtained at

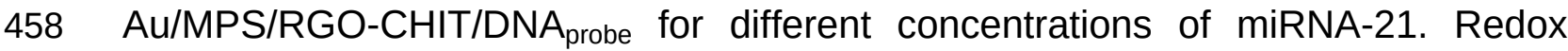
459 marker: $1.0 \times 10^{-3} \mathrm{M}\left[\mathrm{Fe}(\mathrm{CN})_{6}\right]^{3-} /\left[\mathrm{Fe}(\mathrm{CN})_{6}\right]^{4-}$. Other conditions as in Figure 2.

460

461 Figure 4. Charge transfer resistances obtained at GCE/MPS/RGO-CHIT/DNA in the 462 presence of $1.0 \times 10^{-9} \mathrm{M}$ miRNA-21, 1-base-missmatch, and fully non463 complementary sequences. Hybridization time: 75 min. Other conditions as in Figure 4642.

465

466 Table 1. Comparison of the analytical parameters for the most relevant miRNA-21 467 electrochemical biosensors reported in the last two years. 
469 Figure 1-SI. UV-vis spectra corresponding to GO-CHIT (-) and RGO-CHIT (-)

470

471 Figure 2-SI. Effect of the hybridization time at Au/MPS/RGO-CHIT/DNA/Alb on the

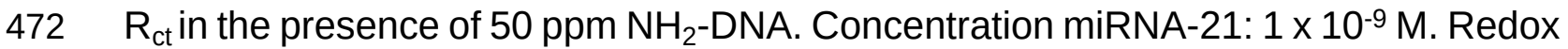
473 marker: $1.0 \times 10^{-3} \mathrm{M}\left[\mathrm{Fe}(\mathrm{CN})_{6}\right]^{3-} /\left[\mathrm{Fe}(\mathrm{CN})_{6}\right]^{4-}$; Frequency range: $10 \mathrm{KHz}$ to $10 \mathrm{mHz}$; 474 Potential amplitude: $10 \mathrm{mV}$; Working potential: $0.200 \mathrm{~V}$. Supporting electrolyte: $4750.050 \mathrm{M}$ phosphate buffer solution $\mathrm{pH}=7.40$ with $0.500 \mathrm{M} \mathrm{NaCl}$. 476

477

478

479

480

481

482 


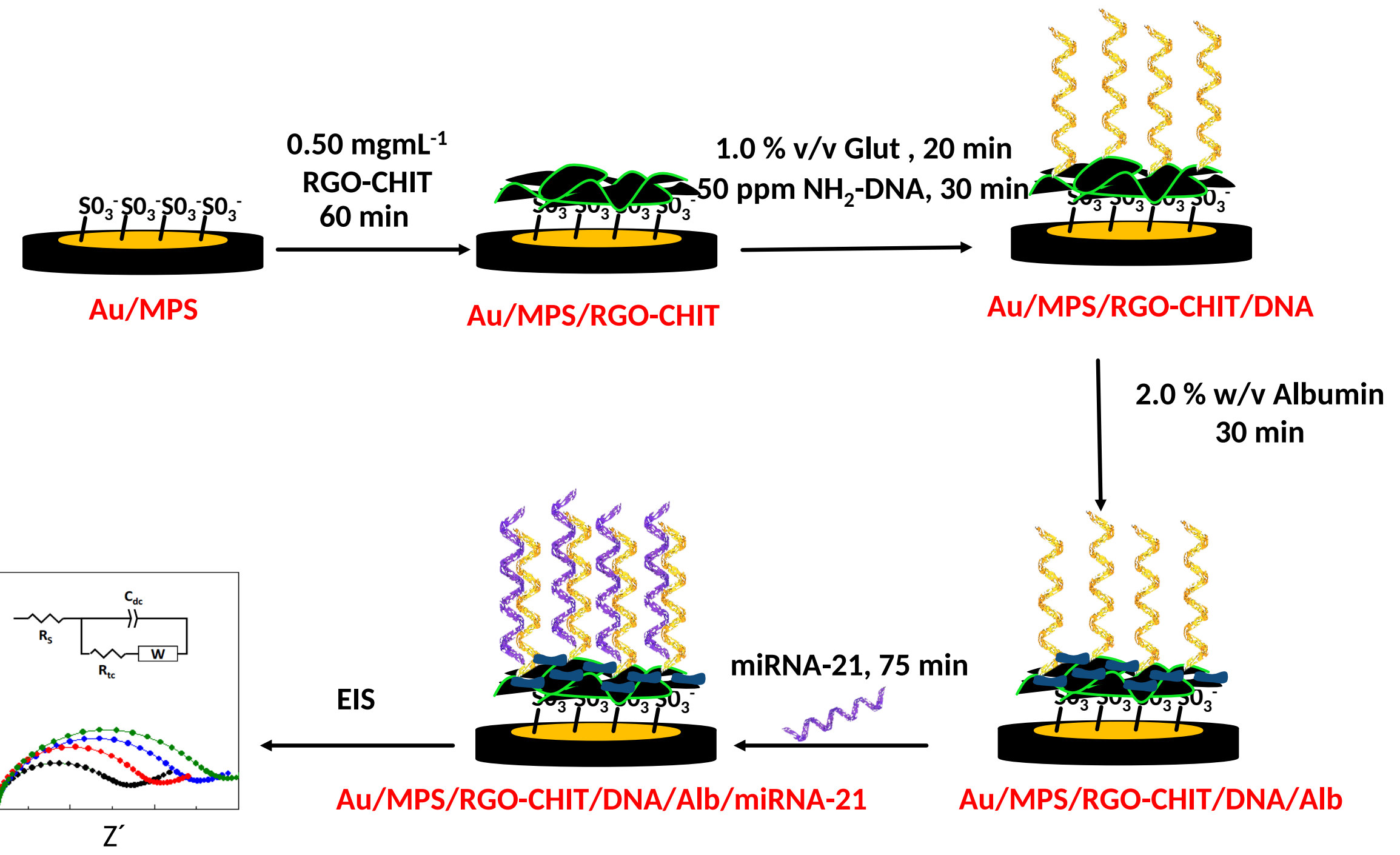

Figure 1. Different steps during the building of the miRNA-21 genosensor. 

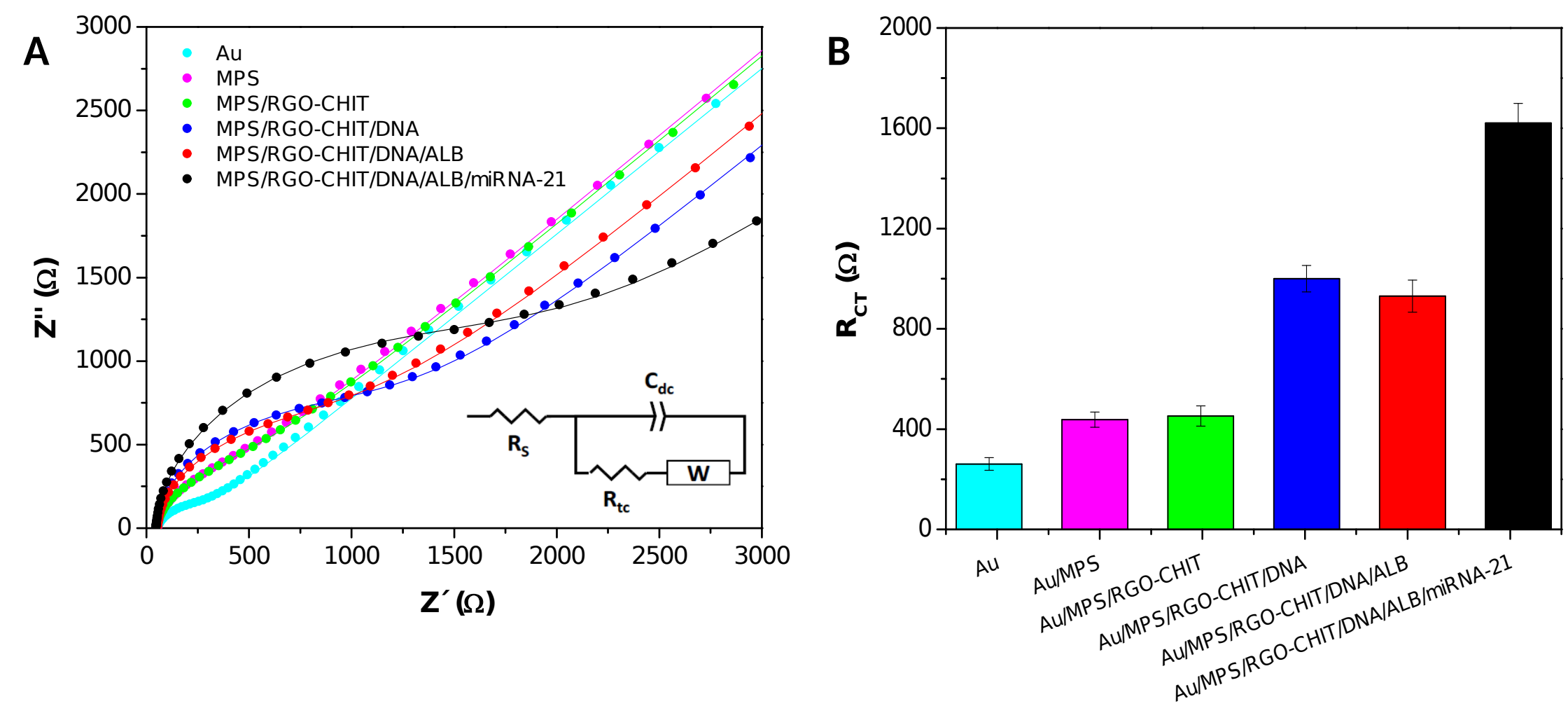

Figure 2. (A) Nyquist plots obtained during the construction of biosensor. Inset: Equivalent circuit used to fit the experimental results (B) Charge transfer resistance after each step during the construction of the biosensing layer and after the hybridization with $1.0 \times 10^{-8} \mathrm{M}$ miRNA-21. Redox marker: $1.0 \times 10^{-3} \mathrm{M}\left[\mathrm{Fe}(\mathrm{CN})_{6}\right]^{3-} /\left[\mathrm{Fe}(\mathrm{CN})_{6}\right]^{4-}$; Frequency range: $10 \mathrm{KHz}$ to $10 \mathrm{mHz}$; Potential amplitude: $10 \mathrm{mV}$; Working potential: $0.200 \mathrm{~V}$. Supporting electrolyte: $0.050 \mathrm{M}$ phosphate buffer solution $\mathrm{pH} 7.40$ with $0.500 \mathrm{M} \mathrm{NaCl}$. 

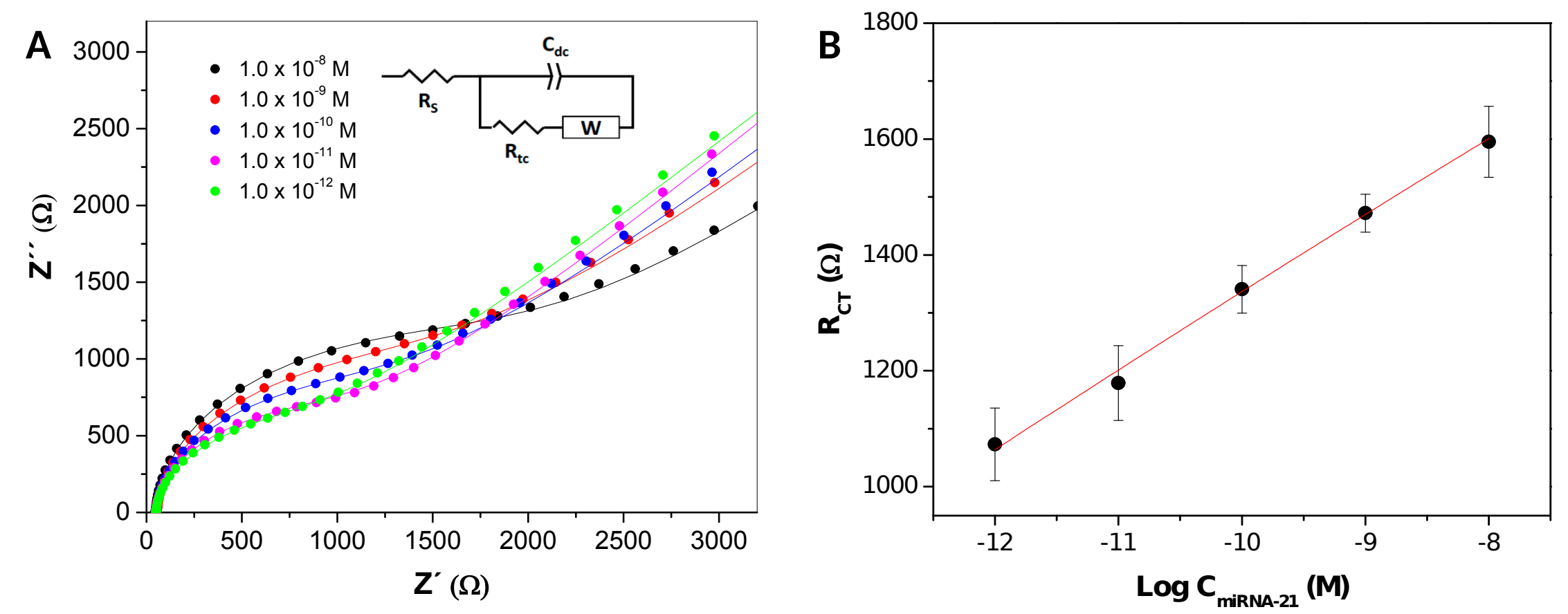

Figure 3. (A) Nyquist plots for $1.0 \times 10^{-3} \mathrm{M}\left[\mathrm{Fe}(\mathrm{CN})_{6}\right]^{3-} /\left[\mathrm{Fe}(\mathrm{CN})_{6}\right]^{4-}$ obtained at Au/MPS/RGO-CHIT/DNA for different concentrations of miRNA-21. Redox marker: $1.0 \times 10^{-3} \mathrm{M}\left[\mathrm{Fe}(\mathrm{CN})_{6}\right]^{3-} /\left[\mathrm{Fe}(\mathrm{CN})_{6}\right]^{4-}$. Other conditions as in Figure 2. 


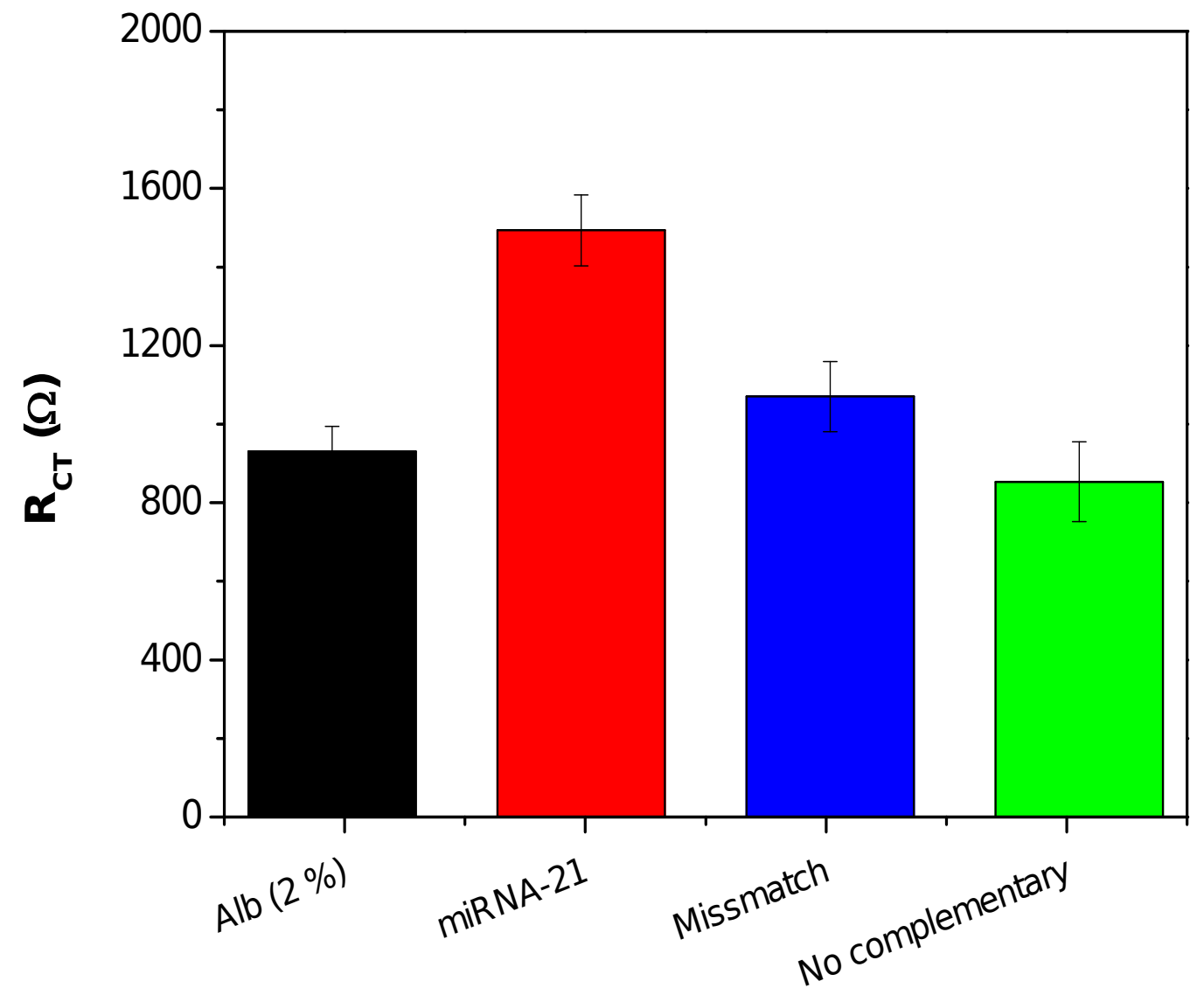

Figure 4. Charge transfer resistances obtained at GCE/MPS/RGO-CHIT/Alb/DNA in the presence of $1.0 \times 10^{-9} \mathrm{M}$ miRNA21, 1-base-missmatch and fully non-complementary sequences. Hybridization time: 75 min. Other conditions as in Figure 2. 


\begin{tabular}{|c|c|c|c|c|c|c|}
\hline Technique & Electrode & Platform and detection & DL & LR & Real sample & Ref. \\
\hline Amperometry & $\mathrm{Au}$ & $\begin{array}{l}\text { Hairpin DNA modified-gold electrode, DSN- } \\
\text { assisted target recycling, biotinylated signaling } \\
\text { DNA/streptavidin-AuNPs to anchor the biotinylated } \\
\text { HRP. }\end{array}$ & $43 \mathrm{aM}$ & $0.1 \mathrm{fM}$ to $100 \mathrm{pM}$ & Tumor cells & [8] \\
\hline DPV & $\mathrm{Au}$ & $\begin{array}{l}\text { G-rich long ssDNAs generated by RCA to facilitate } \\
\text { the in situ synthesis of PdNPs. }\end{array}$ & $8.6 \mathrm{aM}$ & $50 \mathrm{aM}$ to $100 \mathrm{fM}$ & Human serum & [9] \\
\hline DPV & $\mathrm{Au}$ & $\begin{array}{l}\text { Integration of a dual signal amplification strategy of } \\
\text { HCR and EIM, using capture probe (CP H1) } \\
\text { modified magnetic nanobeads. }\end{array}$ & $0.84 \mathrm{fM}$ & $1.0 \times 10^{-15} \mathrm{M}$ to $1.0 \times 10^{-8} \mathrm{M}$ & Human serum & [10] \\
\hline DPV & MGCE & $\begin{array}{l}\text { Capture hairpin immobilized at } \mathrm{Fe}_{3} \mathrm{O}_{4} \text {, } \\
\text { amplification using HCR and detection from the } \\
\text { synergistic reduction of hydrogen peroxide/ TMB } \\
\text { system in the presence of a } \mathrm{Cu} \text { (II) planar complex. }\end{array}$ & $33 \mathrm{aM}$ & $100 \mathrm{aM}$ to $100 \mathrm{nM}$ & Human serum & [11] \\
\hline DPV & $\mathrm{Au}$ & $\begin{array}{l}\text { Amplification scheme based on HCR, which leads } \\
\text { to extended growth of DNA chains and higher } \\
\text { amplification efficiency through MB intercalation. }\end{array}$ & $11 \mathrm{pM}$ & $30 \mathrm{pM}$ to $7.0 \mathrm{nM}$ & Human serum & [12] \\
\hline EIS & GCE & $\begin{array}{l}\mathrm{ZrO}_{2} / \mathrm{rGO} / \text { modified electrode coupled with } \mathrm{CHA} \\
\text { signal amplification strategy and detection through } \\
\text { the change of charge transfer resistance of } \\
{\left[\mathrm{Fe}(\mathrm{CN})_{6}\right]^{3-/ 4-}}\end{array}$ & $4.3 \times 10^{-15} \mathrm{M}$ & $1.0 \times 10^{-14} \mathrm{M}$ to $1.0 \times 10^{-10} \mathrm{M}$ & $\begin{array}{l}\text { MCF7 cells and } \\
\text { human embryonic } \\
\text { kidney cells }\end{array}$ & [13] \\
\hline Chronocoulometry & $\mathrm{Au}$ & $\begin{array}{l}\text { Triple signal amplification based on target- } \\
\text { triggered cyclic duplex specific nuclease digestion } \\
\text { and bridge DNA/AuNPs; detection from the } \\
\text { preconcentrated }\left[\mathrm{Ru}\left(\mathrm{NH}_{3}\right)_{6}\right]^{3+} \text {. }\end{array}$ & $6.8 \mathrm{aM}$ & $1.0 \times 10^{-17} \mathrm{M}$ to $1.0 \times 10^{-11} \mathrm{M}$ & Human serum & [14] \\
\hline Chronocoulometry & SPE & $\begin{array}{l}\mathrm{MoS}_{2} @ \text { AuNPs/capture DNA and detection through } \\
\text { the }\left[\mathrm{Ru}\left(\mathrm{NH}_{3}\right)_{6}\right]^{3+} \text { electrostatically bond to the } \\
\text { surface hybrid. }\end{array}$ & $100 \mathrm{aM}$ & $10 \mathrm{fM}$ to $10 \mathrm{pM}$ & - & [15] \\
\hline Chronocoulometry & SPCE & $\begin{array}{l}\text { GO-loaded iron oxide and detection from } \\
{\left[\mathrm{Ru}\left(\mathrm{NH}_{3}\right)_{6}\right]^{3+} \text { catalyzed by }\left[\mathrm{Fe}(\mathrm{CN})_{6}\right]^{3-} \text {. }}\end{array}$ & $1.0 \mathrm{fM}$ & $1.0 \mathrm{fM}$ to $1.0 \mathrm{nM}$ & $\begin{array}{l}\text { Ovarian cancer } \\
\text { and normal non- } \\
\text { cancerous cells }\end{array}$ & [16] \\
\hline SWV & $\mathrm{Au}$ & Thiol-modified hairpin capture probe immobilized & $0.5 \mathrm{fM}$ & $1.0 \mathrm{fM}$ to $1.0 \mathrm{nM}$ & Human serum & [17] \\
\hline
\end{tabular}


at $\mathrm{Au}$, detection carried out through the

molybdophosphate accumulated at the ribose-

phosphate backbone of the resulting duplex.

SWV

Amperometry

SPCE

DPV

GCE

DPV

DPV

SPE

CV

DPV

FTO

SWV
Mesoporous silica nanospheres-hairpin H1, CHA and HCR enzyme-free amplification, and detection from the nanospheres-released MB.

Ratiometric scheme based on target driven CHA mismatched using three hairpins. Detection from the currents ratio of two redox markers before and after hybridization.

Geno- and immunoassay using anti DNA-RNA antibody and detection from the bacterial protein $A$ conjugated with poly-HRP40/hydrogen peroxide.

DNA-AuNPs, miRNA-21 and MWCNTs modified with a signaling DNA and labeled with thionine.

LNA-modified "Y" shape-like structure and detection of exosomal miRNA-21 based on the distance-sensitive currents ratio of two redox markers.

Immobilized p19 protein with MCF-exosome

biomarkers and subsequent detection due activation of the system by target addition.

Electrode modified with polypyrrol/Ag and pyrrolidinyl PNA and detection through the decrease of Ag oxidation signal.

CGO/Au-PtBNPs/SA/CP using $\left[\mathrm{Fe}(\mathrm{CN})_{6}\right]^{3-/ 4}$ as redox probe.

$\mathrm{MoS}_{2}$-Thi-AuNPs nanohybrid as a signaling
$0.037 \mathrm{fM}$

$0.1 \mathrm{fM}$ to $5.0 \mathrm{pM}$

Liver

hepatocellular

cells

$1.1 \mathrm{fM}$

$5.0 \mathrm{fM}$ to $0.1 \mathrm{nM}$

Cell extraction samples from the

MCF7

$0.4 \mathrm{pM} \quad 1.0 \mathrm{pM}$ to $100 \mathrm{pM}$

Cancer cells and umor tissues

$0.032 \mathrm{pM}$

$0.1 \mathrm{pM}$ to $12000 \mathrm{pM}$

$2.3 \mathrm{fM}$

$10 \mathrm{fM}-70 \mathrm{fM}$

Exosomes

samples

$1.0 \mathrm{aM}$

$1.0 \mathrm{pM}$ to $100 \mathrm{~nm}$

$10 \mathrm{fM}$

$1.0 \times 10^{-13} \mathrm{M}$ to $1.0 \times 10^{-8} \mathrm{M}$

Human plasma

$1.0 \mathrm{fM}$

$1.0 \mathrm{fM}$ to $1.0 \mu \mathrm{M}$

Human serum

$0.26 \mathrm{pM}$

$1.0 \mathrm{pM}$ to $10 \mathrm{nM}$

Human serum 
DL: detection limit; LR: linear range; DSN: duplex-specific nuclease; AuNPs: gold nanoparticles; HRP: horseradish peroxidase; DPV: differential pulse voltammetry; ssDNA: single-stranded DNA; RCA: rolling circle amplification; PdNPs: palladium nanoparticles; HCR: hybridization chain reaction; EIM: enzyme-induced metallization; MGCE: magnetic glassy carbon electrode;

TMB: 3,3',5,5'-tetramethylbenzidine; MB: methylene blue; EIS: electrochemical impedance spectroscopy; GCE: glassy carbon electrodes; rGO: reduced graphene oxide; CHA: catalytic hairpin assembly; MCF7: human breast cancer cell lines; SPE: screen-printed electrode; SPCE: screen-printed carbon electrode; GO: graphene oxide; SWV: square wave voltammetry; MWCNTs: multiwalled carbon nanotubes; LNA: locked nucleic acid; p19: RNA silencing suppressor; CV: cyclic voltammetry; PNA: peptide nucleic acid; FTO: fluorine tin oxide; CGO: carboxylated graphene oxide; Au-PtBNPs: Au-Pt bimetallic nanoparticles; SA: streptavidin; CP: capture probe; Thi: thionine.

Table 1. Comparison of the analytical parameters for the most relevant miRNA-21 electrochemical biosensors reported in the last two years. 